\title{
Oridonin stabilizes retinoic acid receptor alpha through ROS-activated NF-KB signaling
}

Yang $\mathrm{CaO}^{1+}$, Wei Wei ${ }^{2+}$, Nan Zhang ${ }^{1}$, Qing Yu' ${ }^{1}$, Wen-Bin Xu' ${ }^{1}$, Wen-Jun Yu' ${ }^{1}$ Guo-Qiang Chen ${ }^{3}$, Ying-Li Wu ${ }^{3 *}$ and Hua Yan ${ }^{1 *}$

\begin{abstract}
Background: Retinoic acid receptor alpha (RARa) plays an essential role in the regulation of many biological processes, such as hematopoietic cell differentiation, while abnormal RARa function contributes to the pathogenesis of certain diseases including cancers, especially acute promyelocytic leukemia (APL). Recently, oridonin, a natural diterpenoid isolated from Rabdosia rubescens, was demonstrated to regulate RARa by increasing its protein level. However, the underlying molecular mechanism for this action has not been fully elucidated.
\end{abstract}

Methods: In the APL cell line, NB4, the effect of oridonin on RARa protein was analyzed by western blot and real-time quantitative RT-PCR analyses. Flow cytometry was performed to detect intracellular levels of reactive oxygen species (ROS). The association between nuclear factor-kappa B (NF-KB) signaling and the effect of oridonin was assessed using specific inhibitors, shRNA gene knockdown, and immunofluorescence assays. In addition, primary leukemia cells were treated with oridonin and analyzed by western blot in this study.

Results: RARa possesses transcriptional activity in the presence of its ligand, all-trans retinoic acid (ATRA). Oridonin remarkably stabilized the RARa protein, which retained transcriptional activity. Oridonin also moderately increased intracellular ROS levels, while pretreatment with the ROS scavenger, $\mathrm{N}$-acetyl-I-cysteine (NAC), dramatically abrogated RARa stabilization by oridonin. More intriguingly, direct exposure to low concentrations of $\mathrm{H}_{2} \mathrm{O}_{2}$ also increased RARa protein but not mRNA levels, suggesting a role for ROS in oridonin stabilization of RARa protein. Further investigations showed that NAC antagonized oridonin-induced activation of NF-KB signaling, while the NF-KB signaling inhibitor, Bay 11-7082, effectively blocked the oridonin increase in RARa protein levels. In line with this, over-expression of IKBa (A32/36), a super-repressor form of IkBa, or NF-kB-p65 knockdown inhibited oridonin or $\mathrm{H}_{2} \mathrm{O}_{2}{ }^{-}$ induced RARa stability. Finally, tumor necrosis factor alpha (TNFa), a classical activator of NF-kB signaling, modulated the stability of RARa protein.

Conclusions: Oridonin stabilizes RARa protein by increasing cellular ROS levels, which causes activation of the NF-KB signaling pathway.

Keywords: RARa, Oridonin, ROS, NF-KB

\footnotetext{
* Correspondence: wuyingli@shsmu.edu.cn; yanhua_candy@163.com

${ }^{\dagger}$ Equal contributors

${ }^{3}$ Department of Pathophysiology, Chemical Biology Division of Shanghai Universities E-Institutes, Key Laboratory of Cell Differentiation and Apoptosis of National Ministry of Education, Shanghai Jiao-Tong University School of Medicine, Shanghai, China

'Department of Hematology, Rui-Jin Hospital, Shanghai Jiao-Tong University School of Medicine, Shanghai, China

Full list of author information is available at the end of the article
} 


\section{Background}

Retinoid receptors are retinoid ligand-activated transcription factors that are divided into retinoic acid receptors (RARs) and retinoid X receptors (RXRs). Both RARs and RXRs have three isoforms, including RAR $\alpha / \beta$ / $\gamma$ and $\operatorname{RXR} \alpha / \beta / \gamma$. These proteins are encoded by distinct loci and exist as alternatively spliced variants [1]. Active retinoid receptors consist of RAR/RXR heterodimers, which activate the transcription of many target genes by binding retinoic acid responsive elements in promoter and/or enhancer regions. They exert many essential and potent biological functions with respect to the regulation of cell proliferation, differentiation, apoptosis, and autophagy [2-4]. Accordingly, retinoids and their receptors are also widely involved in the pathogenesis of many diseases, especially cancers [5]. A typical example is that of acute promyelocytic leukemia (APL), a unique subtype of acute myeloid leukemia (AML). Almost all APL patients carry chromosome translocations involving $R A R \alpha$, most of which are $\mathrm{t}(15 ; 17)$. This causes fusion of the promyelocytic leukemia $(P M L)$ gene to the $R A R \alpha$ gene and expression of a $P M L-R A R \alpha$ fusion gene, leading to impaired retinoid signaling and pathogenesis of APL. Importantly, all-trans retinoic acid (ATRA) and arsenic trioxide target the PML-RAR $\alpha$ fusion protein to induce differentiation and/or apoptosis of leukemia-initiating cells [6-10]. Besides APL, some other types of cancer also present with aberrant expression of RARs. For example, the expression of $R A R \alpha / \beta$ and $R X R \alpha / \beta$ are downregulated in pancreatic ductal adenocarcinoma, which is associated with poor patient survival outcomes [11].

The mechanisms regulating the expression of RARs are not fully understood. ATRA can directly target RAR $\alpha$ to ubiquitin-proteasome degradation in APL and non-APL cells [12], while activation of c-Jun N-terminal kinase (JNK) can contribute to RAR dysfunction by phosphorylating RAR $\alpha$ at Thr181, Ser445, and Ser461. This induces RAR degradation through the ubiquitinproteasome pathway, pointing to JNK as a key mediator of aberrant retinoid signaling in lung cancer cells [13]. Additionally, JNK activation by oxidative stress also suppresses retinoid signaling through proteasomal degradation of RAR $\alpha$ in hepatic cells [14]. More recently, pharicin B, a novel natural ent-kaurene diterpenoid derived from Isodon pharicus leaves, was reported to rapidly stabilize RAR $\alpha$ protein in various AML cell lines and primary leukemic cells from AML patients [15].

Oridonin, another ent-kaurene diterpenoid isolated from Rabdosia rubescens, has a variety of biological effects, such as anti-inflammatory, anti-viral, and antibacterial functions, as well as anti-tumor effects on different cancers including liver [16], prostate [17], breast [18], and leukemia [19]. Accumulating evidence illustrates that oridonin has extensive anti-tumor effects involving regulation of the cell cycle, apoptosis, autophagy, and differentiation [20-22]. Previously, we reported that oridonin could induce ROS-initiated apoptosis and enhance ATRA-induced differentiation in APL cells. Interestingly, the differentiation-enhancing effect of oridonin was accompanied by increased levels of RAR $\alpha$ protein [23]. In this work, we further investigated the mechanisms underlying oridonin stabilization of RAR $\alpha$ protein.

\section{Methods \\ Cells}

NB4/GFP and NB4/GFP-MAD cells were generous gifts from F. Besancon (Hôpital St. Louis, Paris, France). Construction of the two cell lines was described previously by Komura et al. [24]. NB4, NB4/GFP, and NB4/GFPMAD cells were cultured in RPMI 1640 medium (Sigma-Aldrich, St. Louis, MO, USA), supplemented with $10 \%(\mathrm{v} / \mathrm{v})$ heat-inactivated fetal bovine serum (FBS; HyClone, Logan, UT, USA). COS-7 and 293 T cells were cultured in Dulbecco's modified Eagle's medium (Life Technologies, USA), supplemented with $10 \%$ FBS in a humidified incubator at $37^{\circ} \mathrm{C}$ with $5 \% \mathrm{CO}_{2} / 95 \%$ air (v/v).

\section{Reagents and antibodies}

Oridonin (purity >99.5\%) was purchased from Xi'an Haoxuan Biotechnique, China. It was dissolved in dimethyl sulfoxide (DMSO) at a stock concentration of $10 \mathrm{mM}$ and stored at $-20^{\circ} \mathrm{C}$. Both $N$-acetyl-l-cysteine (NAC) and ATRA were purchased from Sigma-Aldrich. Recombinant human tumor necrosis factor (TNFa) was obtained from Peprotech (Rocky Hill, NJ, USA). Cycloheximide was purchased from Sigma-Aldrich. ERK inhibitor PD98059, p38 inhibitor SB203580, JNK inhibitor SP600125, and NF-kB inhibitor Bay 11-7082 were purchased from Santa Cruz Biotechnology (Santa Cruz, CA, USA). When cells were treated with these reagents, matching concentrations of vehicle were used as the control and the final concentration of DMSO was kept at or below $0.1 \%$ in all experiments.

Antibodies recognizing $\mathrm{p} 65$, IкB $\alpha$, and RAR $\alpha$ were purchased from Santa Cruz Biotechnology. Antibodies recognizing phospho-ІкB $\alpha$ (Ser32/Ser36), phospho-p65, ІкB kinase beta (IKK $\beta)$, phospho-IKK $\alpha / \beta$, phospho-ERK1/ ERK2, ERK1/ERK2, phospho-p38, p38, phospho-JNK, and JNK were purchased from Cell Signaling Technology (Beverly, MA, USA).

\section{Western blot}

Equal amounts of protein extracts were loaded onto a sodium dodecyl sulfate-polyacrylamide gel electrophoresis (SDS-PAGE) system, electrophoresed, and transferred to nitrocellulose membranes (Amersham). After blocking with 5\% (w/v) nonfat milk in PBS for 2 hours at room temperature, the membranes were incubated 
with specific antibodies overnight, followed by incubation with horseradish peroxidase-linked secondary antibody (Cell Signaling Technology) for 1 hour at room temperature. The signals were detected by the chemiluminescence phototope-HRP kit (Millipore), according to the manufacturer's instructions. $\beta$-actin was probed as an internal control. All experiments were repeated three times, and similar results were obtained.

\section{RNA extraction and real-time quantitative RT-PCR}

The cells were lysed, and total RNA was isolated using a TRIzol kit (Invitrogen). Then, the RNA was treated with DNase (Promega). Complementary DNA was synthesized according to the manufacturer's instructions. Realtime quantitative RT-polymerase chain reactions (PCRs) for RAR $\alpha$, retinoic acid receptor beta (RAR $\beta)$, CCAAT/ enhancer binding protein-beta (C/EBP- $\beta)$, retinoic acidinduced genes $\mathrm{E}$ (RIG-E) and interferon regulatory factor 1 (IRF-1), were performed with SYBR Green PCR Master Mixture Reagents (Applied Biosystems) on the Applied Biosystems 7300 real-time RT-PCR system. The specific primers used as follows: 5'-TCTGTGAGAAACGACCG AAAC-3' and 5'-TGAGGGTGGT GAAGCCG-3' for RAR $\alpha$ gene, 5' ${ }^{\prime}$-AGTTTGATGGAGTTGGG TGGAC-3' and $5^{\prime}$-GATGCTGCCATTCGGTTTG-3' for RAR $\beta, 5^{\prime}$-T CAGCACCC TGCGGAACTT-3' and 5'-AAGTGCCCCA GTGCCAAAG-3' for C/EBP $\beta$, 5' -AGG GAGACCGTG TCAGTA GGG-3' and 5' -CGGAAGTGGCAGAAACC CC-3' for RIG-E, and 5'-ATGAGACCCTGGCTAGA G-3' and 5'-AAGCATCCGGTAC ACTCG-3' for IRF-1. The primers were synthesized by Sangon Biotech (Shanghai, China). All experiments were performed in triplicate. Data were normalized to the housekeeping gene $\beta$-actin, and the relative abundance of transcripts was calculated by the comparative $\Delta \Delta C T$ method.

\section{Redox diagonal electrophoresis}

The samples were prepared in $1 \times$ SDS sample buffer without any reducing agent and loaded onto 10\% SDS-PAGE gels. After the first dimension, non-reducing electrophoresis, the entire lane containing the separated proteins was excised and soaked for 20 min in SDS sample buffer containing $100 \mathrm{mM}$ dithiothreitol to reduce any disulfide bonds present between proteins or within proteins. The gel lane was then rotated 90 degrees and placed horizontally on top of a large-format, 1.5 -mm-thick $10 \%$ acrylamide gel. Under these conditions, the proteins that do not form disulfide bond electrophorese identically in both dimensions and form a diagonal after the second dimension. In contrast, proteins that contain intra-chain disulfide bond lie above this diagonal, while those that form inter-disulfide bond fall below the diagonal. Finally, immunoblot was performed to identify the dots containing RAR $\alpha$.

\section{Detection of intracellular ROS level}

The cells were incubated with $2^{\prime}, 7^{\prime}$-dichlorodihydrofluorescein diacetate $\left(\mathrm{H}_{2} \mathrm{DCFDA}\right)$ (Molecular Probes/Invitrogen) in $\mathrm{PBS}$ for $30 \mathrm{~min}$ at $37^{\circ} \mathrm{C}$ while protected from light. The fluorescence intensity, which resulted from the oxidation of the dye, was measured by fluorescence-activated cell sorting (FACS) to determine the level of ROS. The experiments were performed in triplicate.

\section{Plasmid construction and transfection}

Pairs of complementary shRNA oligonucleotides against catalase (5'-AGATGATCTACT CAGAAAT-3'), p65 (5'-GATGAGATCTTCCTACTGT-3'), and non-targeting control NC (5'-TCCCGTGAATTGGAATCCT-3') were synthesized by Sangon Biotech (Shanghai, China), annealed, and ligated into the pSIREN-RetroQ Vector (Clontech Laboratories) between the BamHI and EcoRI sites. A full-length cDNA of human RAR $\alpha$ was amplified from NB4 cells by PCR and cloned into the virus expression vector, pMSCV-puro (Clontech Laboratories). shRNA/ cDNA-carrying retroviruses were produced in $293 \mathrm{~T}$ cells and used to infect NB4 or COS-7 cells. Forty-eight hours after transfection, cells were selected with puromycin (Sigma-Aldrich).

\section{Immunofluorescence assay}

The cells, which were treated as described in the text, were collected onto slides and fixed with $4 \%$ paraformaldehyde. After permeabilization with methanol and blocking with $2 \%(\mathrm{w} / \mathrm{v})$ bovine serum albumin in PBS, the cells were incubated overnight with the antibody against p65. Then, the cells were stained with FITClabeled anti-rabbit IgG for 1 hour. The cell nuclei were stained with 4',6-diamidino-2-phenylindole (DAPI, Molecular Probes, Eugene, OR). The stained cells were visualized by fluorescence microscopy (Olympus BX51; Olympus, Tokyo, Japan).

\section{Patient samples}

Patient samples were collected after obtaining informed consent under a procurement protocol that was approved by the Ethics Committee of Rui-Jin Hospital affiliated to Shanghai Jiao Tong University School of Medicine, Shanghai, China. Mononuclear cells were isolated from bone marrow of AML patients using FicollHypaque liquid (Pharmacia, Piscataway, NJ, USA) and standard procedures.

\section{Statistical analysis}

Results were derived from at least three independent experiments and expressed as the mean \pm standard deviation. The Student's $t$-test was used for statistical analysis. $P<0.05$ was considered to be statistically significant. 


\section{Results \\ Oridonin-induced stabilization of RARa protein in leukemia cells}

Previously, we reported that oridonin increased RAR $\alpha$ protein levels and antagonized ATRA-induced RAR $\alpha$ loss in leukemia cell lines [23]. To further investigate this, we used oridonin to treat primary leukemia cells and the APL cell line, NB4. The effect of oridonin in increasing the levels of RAR $\alpha$ protein could be clearly seen in primary leukemia cells from the bone marrow of three AML patients (Figure 1A). Clinical information of patients is shown in Figure 1B. In NB4 cells, oridonin increased RAR $\alpha$ protein levels in a dose-dependent manner (left panel, Figure 1C). When $10 \mu \mathrm{M}$ of oridonin was applied for $12 \mathrm{~h}$, the levels of RAR $\alpha$ protein became significantly increased (right panel, Figure 1C). More interestingly, oridonin failed to modulate the levels of RAR $\alpha$ mRNA in NB4 cells (Figure 1D). Moreover, we stably transfected RAR $\alpha$-expressing plasmids into COS7 cells, and found that oridonin could also increase levels of the ectopically expressed RAR $\alpha$ protein (data not shown). These data suggest that oridonin regulates RAR $\alpha$ at the post-transcriptional level. In line with this notion, oridonin delayed the degradation of RAR $\alpha$ protein in NB4 cells treated with oridonin plus cycloheximide $(\mathrm{CHX})$ compared with cells treated with CHX alone for different times (Figure 1E). We also determined the mRNA levels of four known RAR $\alpha$-targeted genes, RAR $\beta$, C/EBP- $\beta$, RIG-E, and IRF-1, in NB4 cells with or without oridonin $(10 \mu \mathrm{M})$ and/or ATRA (10 nM) treatment. Consistent with previous reports [25-28], ATRA treatment alone increased the expression of all four of these genes, and this expression was significantly enhanced by oridonin (Figure 1F). Of note, oridonin alone also slightly, but significantly, increased the expression of RIG-E and IRF-1 but not of RAR $\beta$ and C/EBP $\alpha$ (Figure 1F). Overall, our results indicate that oridonin can stabilize RAR $\alpha$ protein, which shows transcriptional activity in the presence of its ligand, ATRA.

\section{Involvement of ROS in oridonin-induced RARa stabilization}

Many studies have shown that oridonin can induce oxidative stress $[29,30]$. Indeed, oridonin rapidly and transiently increased intracellular reactive oxygen species (ROS) levels to a moderate but statistically significant degree in NB4 cells, as assessed by flow cytometric measurement of the ROS probe, $\mathrm{H}_{2}$ DCFDA (Figure 2A). To investigate whether the increased levels of ROS were involved in oridonin-induced RAR $\alpha$ stabilization, we treated NB4 cells with $10 \mu \mathrm{M}$ oridonin for an additional $12 \mathrm{~h}$ after pretreatment with or without the ROS scavenger NAC for $1 \mathrm{~h}$, which totally inhibited oridonininduced ROS accumulation (left panel, Figure 2B). Of great importance, NAC pretreatment also dramatically abrogated RAR $\alpha$ stabilization by oridonin (right panel, Figure 2B). This was also true in primary AML cells (Figure 2C).

We then used $\mathrm{H}_{2} \mathrm{O}_{2}$ to treat NB4 cells to determine the potential role of ROS in RAR $\alpha$ stabilization. Intriguingly, direct exposure of a low concentration of $\mathrm{H}_{2} \mathrm{O}_{2}$ obviously increased RAR $\alpha$ protein (Figure 2D-E) but not mRNA levels (Figure 2F) in a dose- and timedependent manner. Furthermore, CHX experiments also demonstrated that $\mathrm{H}_{2} \mathrm{O}_{2}$ delayed the degradation of RAR $\alpha$ protein (Figure 2G). In addition, the specific shRNAmediated knockdown of catalase, a key antioxidant enzyme that eliminates $\mathrm{H}_{2} \mathrm{O}_{2}$ [31], increased endogenous ROS levels in NB4 cells (left panel, Figure 2H). Accordingly, it also increased the abundance of RAR $\alpha$ protein (right panel, Figure 2H). Together, these data indicate that a moderately increased level of ROS mediates RAR $\alpha$ stabilization.

\section{Activation of multiple cellular signaling pathways by oridonin}

Next, we addressed how ROS accumulation increases RAR $\alpha$ stabilization. We tested whether ROS cause the oxidation of RAR $\alpha$ protein by treating NB4 cells with $5 \mu \mathrm{M}$ of $\mathrm{H}_{2} \mathrm{O}_{2}$ for $4 \mathrm{~h}$, followed by redox diagonal electrophoresis [32]. The results showed that $\mathrm{H}_{2} \mathrm{O}_{2}$ did not directly target RAR $\alpha$ protein to cause its oxidative modification (Figure 3A). However, converging lines of evidence indicate that ROS, especially $\mathrm{H}_{2} \mathrm{O}_{2}$, can actually function as signaling messengers and drive several aspects of cellular signaling [33-35]. We showed that oridonin could activate mitogen-activated protein kinases such as ERK1/ERK2 and p38, as well as JNK1 and JNK2, as assessed by their increased phosphorylation (Figure 3B). Of note, levels of phosphorylated ERK1/ERK2 rapidly increased $6 \mathrm{~h}$ after oridonin treatment, and then declined after $12 \mathrm{~h}$, indicating that oridonin activates ERK1/ERK2 over a short time. More interestingly, oridonin could also induce phosphorylation of some important components of NF- $\mathrm{kB}$ signaling, such as inhibitor kappa $B$ alpha $(I \kappa B \alpha)$ and $I K K \alpha / \beta$, indicating that this compound can activate NF- $\mathrm{kB}$ signaling (Figure $3 \mathrm{~B}$ ). In addition, oridonin also induced phosphorylation of NFкB-p65 itself (Figure 3B). Consistently, immunofluorescence staining demonstrated that oridonin treatment induced nuclear localization of NF-kB-p65 (Figure 3C), supporting the idea that oridonin activates NF- $\mathrm{kB}$ signaling.

\section{Suppression of oridonin-induced RARa stability by chemical inhibition of NF-KB signaling}

To figure out which pathway(s) mediate oridonininduced RAR $\alpha$ stability, we used specific inhibitors to 
$\mathbf{A}$

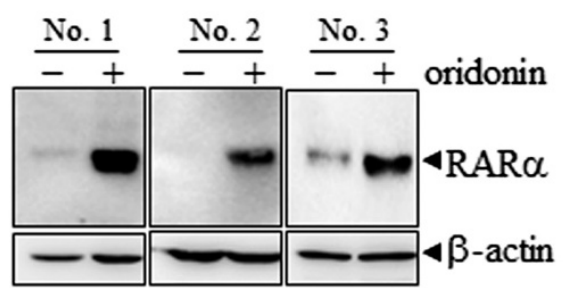

C

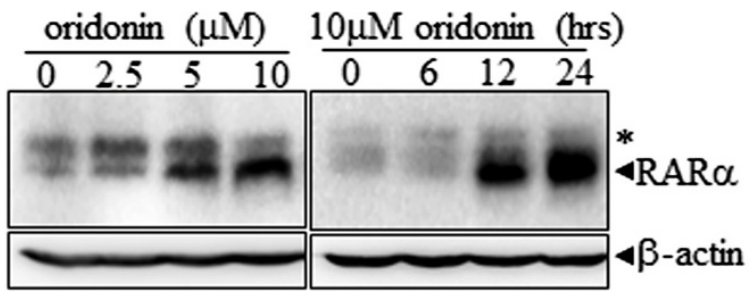

B

\begin{tabular}{|c|c|c|c|c|c|c|}
\hline No. & Sex & $\begin{array}{l}\text { Age } \\
(y)\end{array}$ & $\begin{array}{l}\text { FAB } \\
\text { subtype }\end{array}$ & Chromosome & $\begin{array}{l}\text { Blasts } \\
\%\end{array}$ & $\begin{array}{l}\text { WBC } \\
\left(\times 10^{9} / \mathrm{L}\right)\end{array}$ \\
\hline 1 & $\mathrm{~F}$ & 20 & M3 & $\begin{array}{l}\text { 46, XX [8] /[11] } \\
\text { PML-RAR } \alpha^{+}\end{array}$ & 90 & 1.7 \\
\hline 2 & M & 31 & M3 & $\begin{array}{l}45-46, X Y, t(15 ; 17) \\
\text { PML-RAR } \alpha^{+}\end{array}$ & 92 & 3.87 \\
\hline$\overline{3}$ & M & 58 & M4 & $46, X Y$ & 60 & 66 \\
\hline
\end{tabular}

D

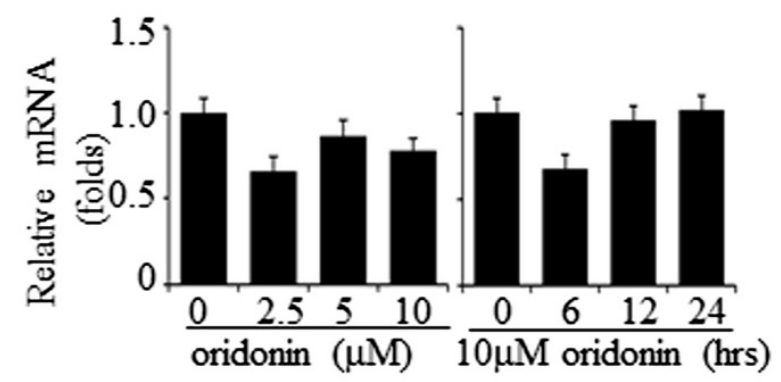

$\mathbf{E}$

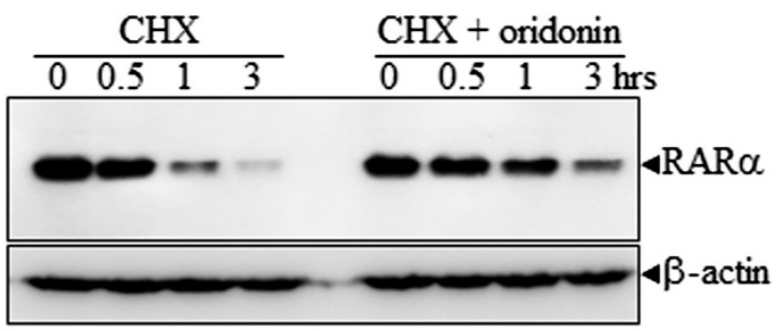

$\mathbf{F}$

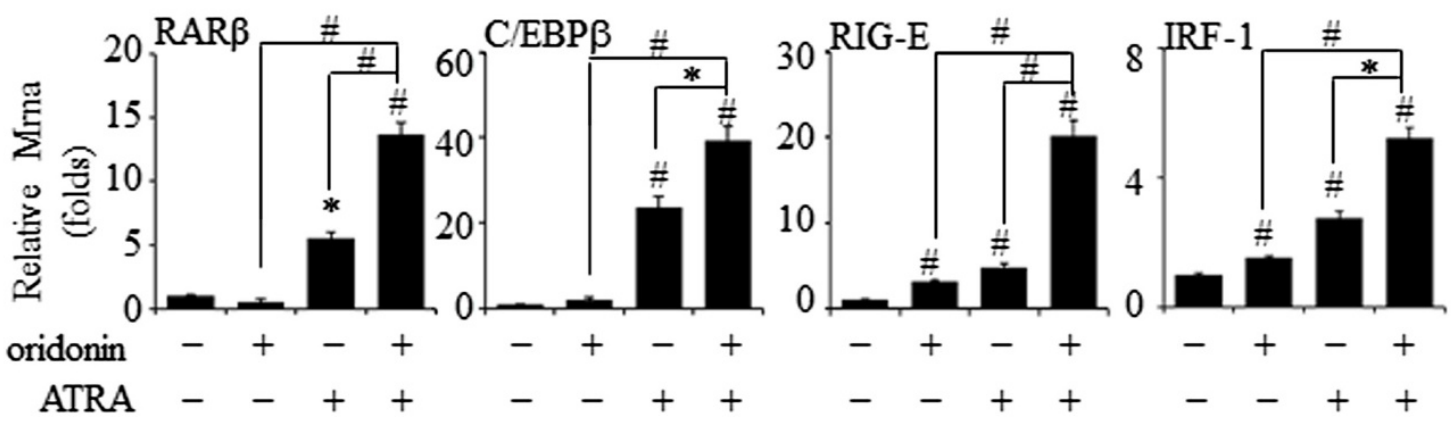

Figure 1 Oridonin stabilizes RARa protein in leukemia cells. (A) Primary leukemia cells from three newly diagnosed AML patients were treated with $10 \mu \mathrm{M}$ oridonin for $12 \mathrm{~h}$, followed by detection of RARa protein with $\beta$-actin as a loading control. (B) Clinical data of the three AML patients. (C) NB4 cells were treated with the indicated concentrations of oridonin for $12 \mathrm{~h}$ (left panel) or with $10 \mu \mathrm{M}$ oridonin for the indicated times (right panel), followed by western blot analysis of the RARa protein with $\beta$-actin as a loading control. The symbol * denotes a non-specific protein. (D) NB4 cells were treated as described in panel C, followed by the quantification of RARa mRNA by real-time RT-PCR. (E) NB4 cells were incubated with $5 \mu \mathrm{g} / \mathrm{mL}$ CHX alone or with $10 \mu \mathrm{M}$ oridonin for the indicated times. Increased amounts of cell lysates compared with panel A were loaded and then blotted for the RARa protein with $\beta$-actin as a loading control. (F) NB4 cells were treated with $10 \mu \mathrm{M}$ oridonin and/or 10 nM ATRA for $48 \mathrm{~h}$, and the mRNA levels of the indicated genes were measured by real-time RT-PCR. The data are represented as fold changes against the control. The symbols * and \# represent $P$ values less than 0.05 and 0.01 , respectively. All experiments were replicated three times and gave consistent results. 
A

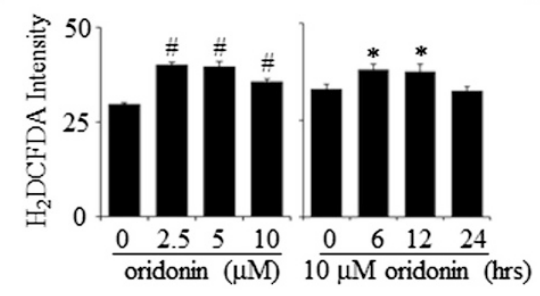

B

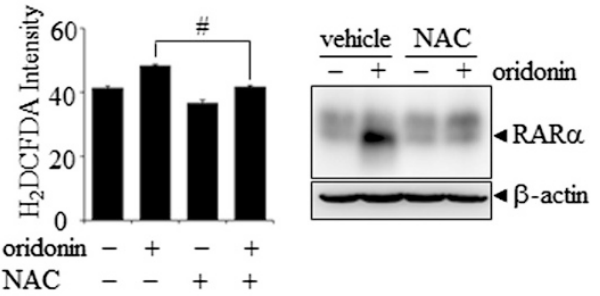

C

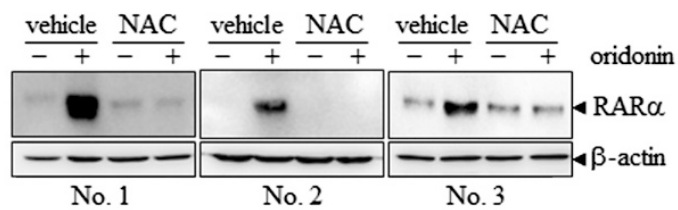

D

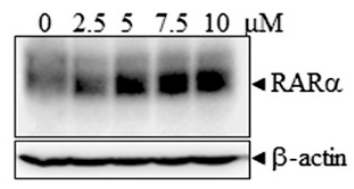

$\mathbf{E}$

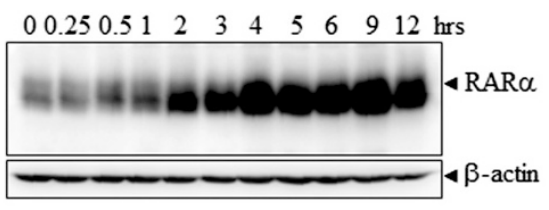

G

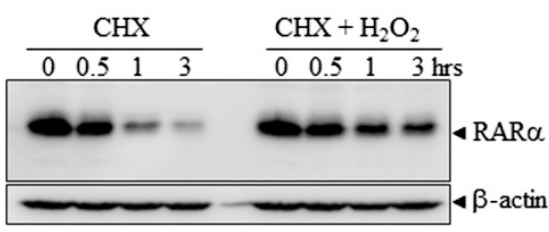

F

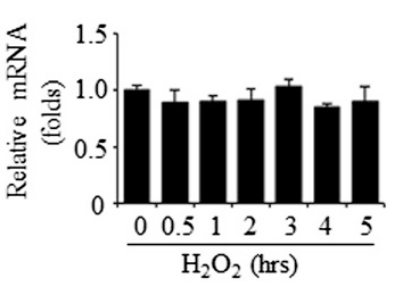

H

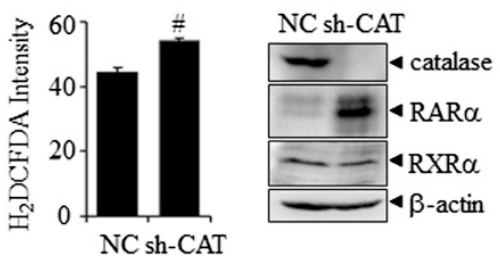

Figure 2 ROS are involved in oridonin-induced RARa stabilization. (A) NB4 cells were treated with the indicated concentrations of oridonin for $12 \mathrm{~h}$ (left panel) or with $10 \mu \mathrm{M}$ oridonin for the indicated times (right panel), followed by detection of ROS levels by flow cytometry. The symbols * and \# represent $P$ values less than 0.05 and 0.01 , respectively. (B) After pretreatment with or without 2 mM NAC for 1 h, NB4 cells were incubated with $10 \mu \mathrm{M}$ oridonin for $12 \mathrm{~h}$, followed by detection of ROS levels by flow cytometry (left panel) and western blot detection for RARa protein with $\beta$-actin as loading control (right panel). The symbol \# represents a $P$ value less than 0.01 . (C) Primary AML cells were treated as NB4 cells in the panel $\mathrm{B}$, and the levels of RARa protein were measured. (D, E) NB4 cells were treated with the indicated concentrations of $\mathrm{H}_{2} \mathrm{O}_{2}$ for $2 \mathrm{~h}(\mathbf{D})$ or with $5 \mu \mathrm{M} \mathrm{H}_{2} \mathrm{O}_{2}$ for the indicated times (E), then the level of RARa protein was assessed. (F) NB4 cells were treated with $5 \mu \mathrm{M} \mathrm{H} \mathrm{H}_{2}$ for the indicated times, and RARa mRNA levels were evaluated by real-time RT-PCR. (G) NB4 cells were incubated with $5 \mu \mathrm{g} / \mathrm{mL} \mathrm{CHX}$ alone or in combination with $5 \mu \mathrm{M} \mathrm{H}_{2} \mathrm{O}_{2}$, followed by western blot detection of RARa protein with $\beta$-actin as loading control. (H) NB4 cells were infected with pSIREN-RetroQ-derived retroviruses carrying shRNA specifically against catalase (sh-CAT) or non-specific scrambled shRNA as a control (NC). Infected cells were assayed for ROS production (left panel) and western blotted for the indicated proteins. The symbol \# represents $P$ values less than 0.01 , respectively. All experiments were repeated three times and gave consistent results.

pretreat NB4 cells for $1 \mathrm{~h}$, followed by oridonin incubation for an additional $12 \mathrm{~h}$. As shown in Figure 4A, pretreatment with PD98059 (ERK inhibitor) or SB203580 (p38 inhibitor) did not influence oridonin-induced RAR $\alpha$ stability. In contrast, the JNK inhibitor, SP600125, could slightly enhance oridonin-increased RAR $\alpha$ protein levels. The effects of these three kinase inhibitors ruled out the involvement of these pathways in oridonin stabilization of RAR $\alpha$. However, use of the NF-kB signaling inhibitor, Bay 11-7082, significantly inhibited oridonin-induced phosphorylation of $\mathrm{I} \kappa \mathrm{B} \alpha$ and $\mathrm{NF}-\kappa \mathrm{B}-\mathrm{p} 65$. Interestingly, pre-incubation with Bay 11-7082 antagonized oridoninincreased RAR $\alpha$ protein levels in NB4 cells, which indicated that activation of the NF- $\mathrm{B}$ p pathway is required for oridonin-induced RAR $\alpha$ stability (Figure 4B). Similar results were achieved in AML patient samples (Figure 4C). In addition, NAC preincubation also blocked oridonininduced phosphorylation of IKK $\alpha / \beta, \mathrm{I} \kappa \mathrm{B} \alpha$ and NF-kB-p65 (Figure 4D), consistent with its inhibitory effect on oridonin-stabilized RAR $\alpha$ (Figure $2 \mathrm{~B}$ and $\mathrm{C}$ ). These data suggested that oridonin stabilized RAR $\alpha$ protein via the ROS-activated NF-kB pathway. 


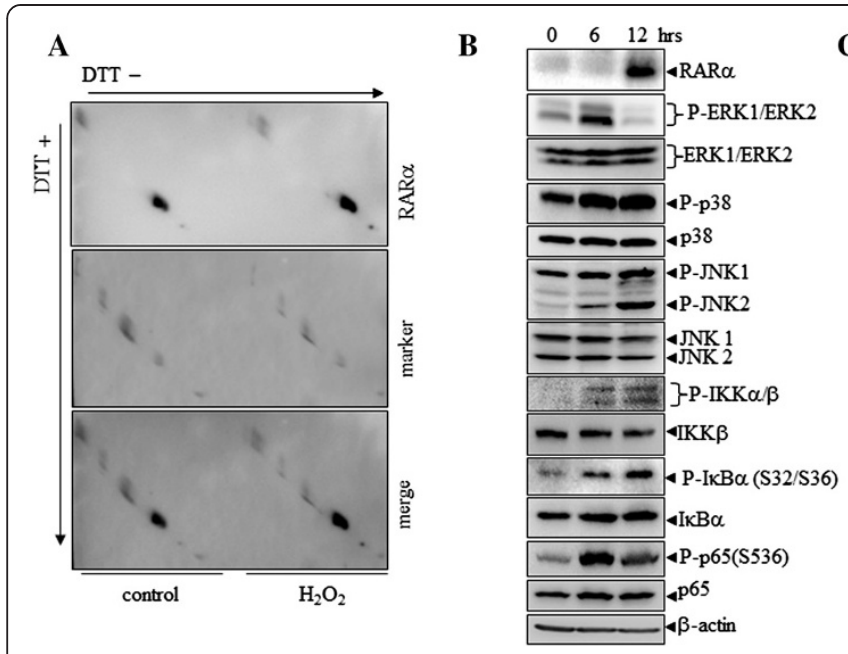

\section{C}
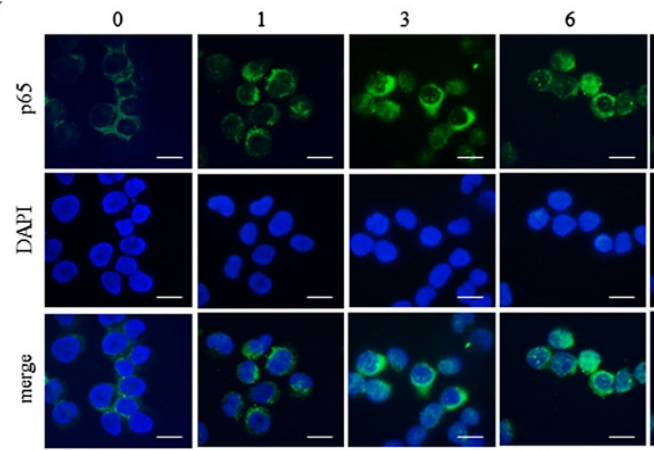

12 hrs

宅
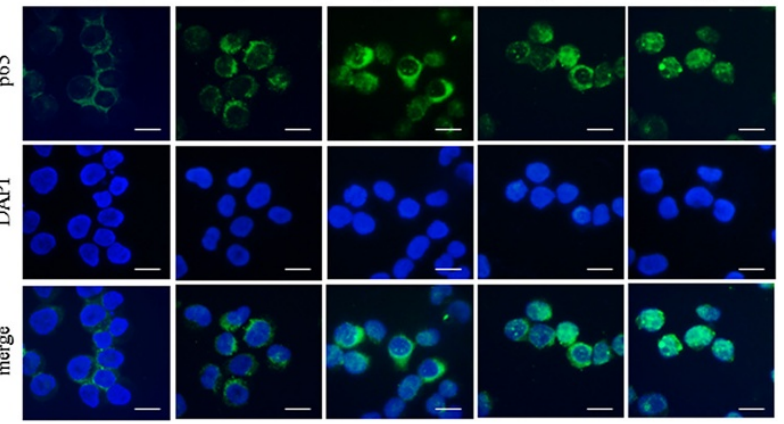

Figure 3 Oridonin activates multiple cellular signaling pathways. (A) NB4 cells were treated with $5 \mu \mathrm{M} \mathrm{H}_{2} \mathrm{O}_{2}$ for 4 h. RARa protein levels were examined by redox diagonal electrophoresis, followed by western blot analysis for RARa. (B) NB4 cells were treated with $10 \mu \mathrm{M}$ oridonin for the indicated times, and cell lysates were western blotted for the proteins indicated. (C) NB4 cells were treated with $10 \mu \mathrm{M}$ oridonin for the indicated times. The intracellular localization of p65 was analyzed by indirect immunofluorescence using anti-p65 antibodies (green). Nuclear DAPI staining (blue) is also shown. Scale bars represent $20 \mu \mathrm{m}$. All experiments were repeated three times and gave consistent results.

$\mathbf{A}$
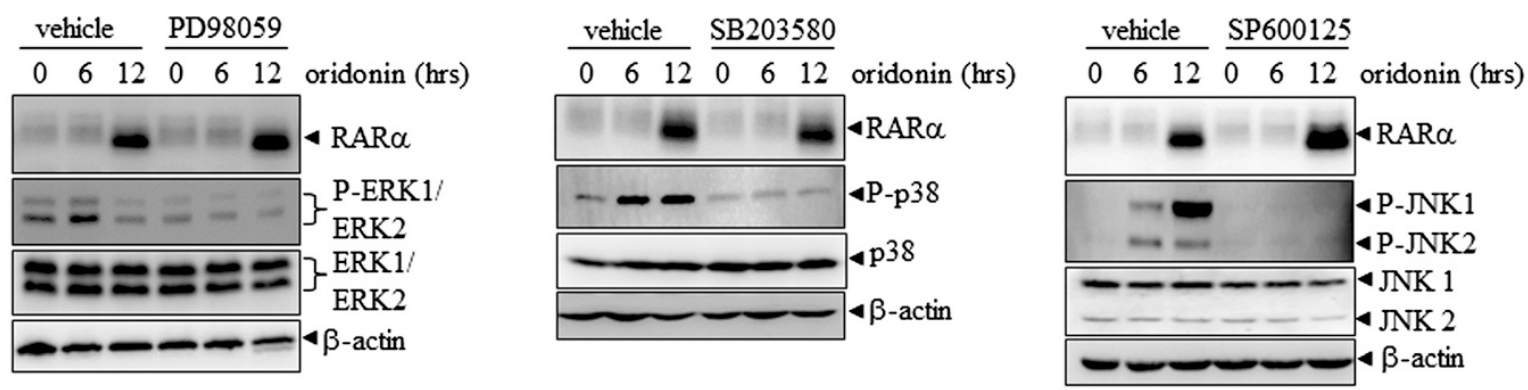

B

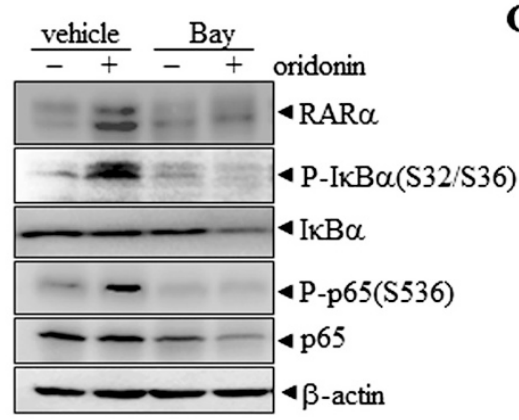

C

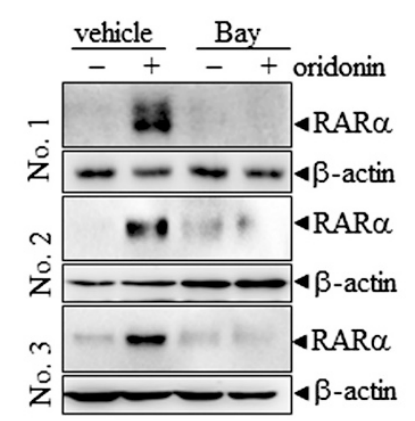

D

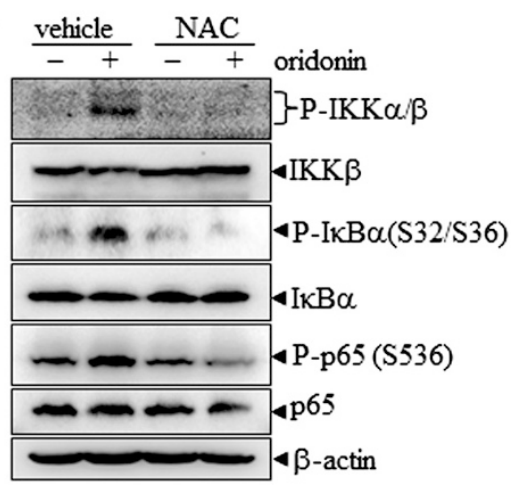

Figure 4 NF-KB inhibitor blocks oridonin-induced RARa stability. After pretreatment with and without PD98059, SB203580, SP600125 (A), Bay 11-7082 (B, C), or NAC (D) for 1 h, NB4 cells or primary AML cells were treated with $10 \mu \mathrm{M}$ oridonin for $12 \mathrm{~h}$, followed by western blot analysis of proteins as indicated. All experiments were repeated three times and gave consistent results. 
Essential role of activation and nuclear translocation of NF-KB for oridonin-induced RARa stability

To confirm that oridonin stabilizes RAR $\alpha$ through the NF-kB pathway, we used NB4/GFP-MAD cells to perform further experiments. This engineered cell line stably expresses the GFP-tagged super-repressor form of $\mathrm{I} \kappa \mathrm{B} \alpha$, namely $\mathrm{I} \kappa \mathrm{B} \alpha(\mathrm{A} 32 / 36)$, which confers cellular resistance to signal-induced phosphorylation and subsequent proteasome-mediated degradation of $\mathrm{I}_{\kappa} \mathrm{B} \alpha$, resulting in the constitutive suppression of NF- $\mathrm{kB}$ activation by sequestering it in the cytoplasm [36]. As shown in Figure 5A, the over-expression of $\mathrm{I}_{\kappa} \mathrm{B} \alpha(\mathrm{A} 32 / 36)$ blocked oridonin-induced nuclear translocation of p65. As expected, both oridonin- and $\mathrm{H}_{2} \mathrm{O}_{2}$-induced RAR $\alpha$ stability

\section{A}
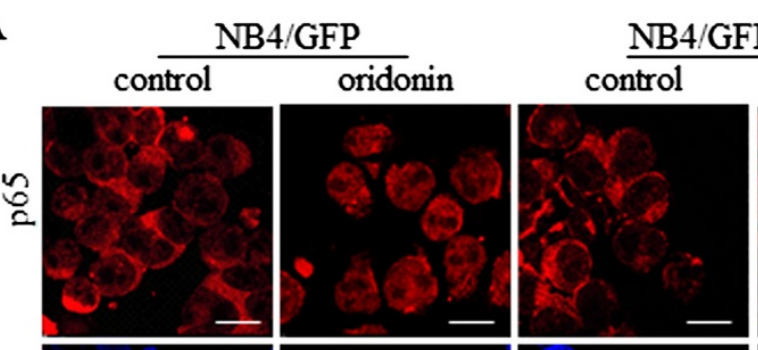

NB4/GFP-MAD
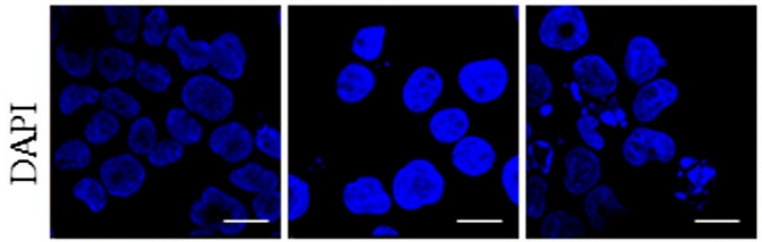

oridonin
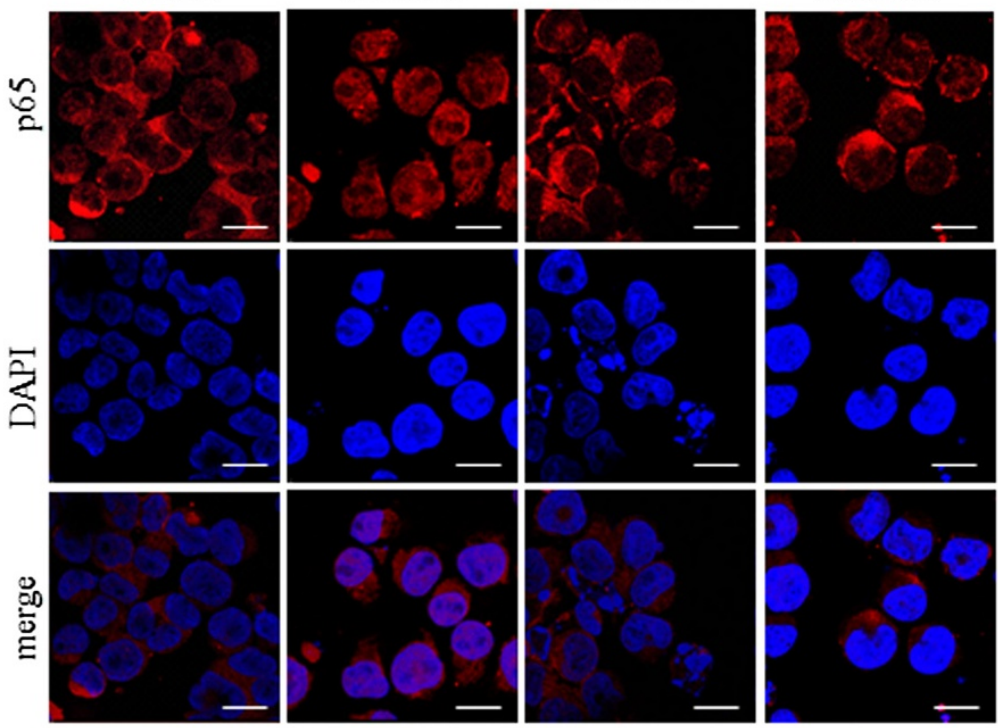

B

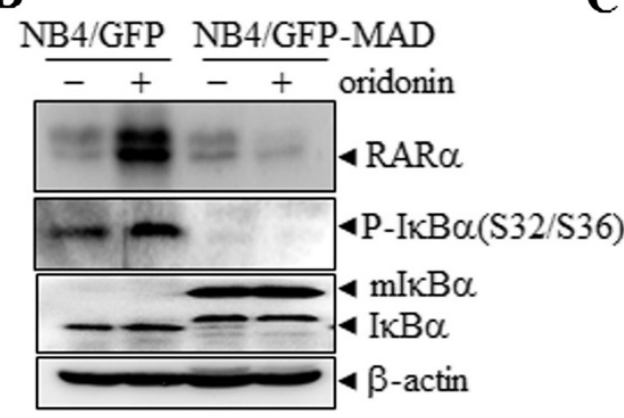

C
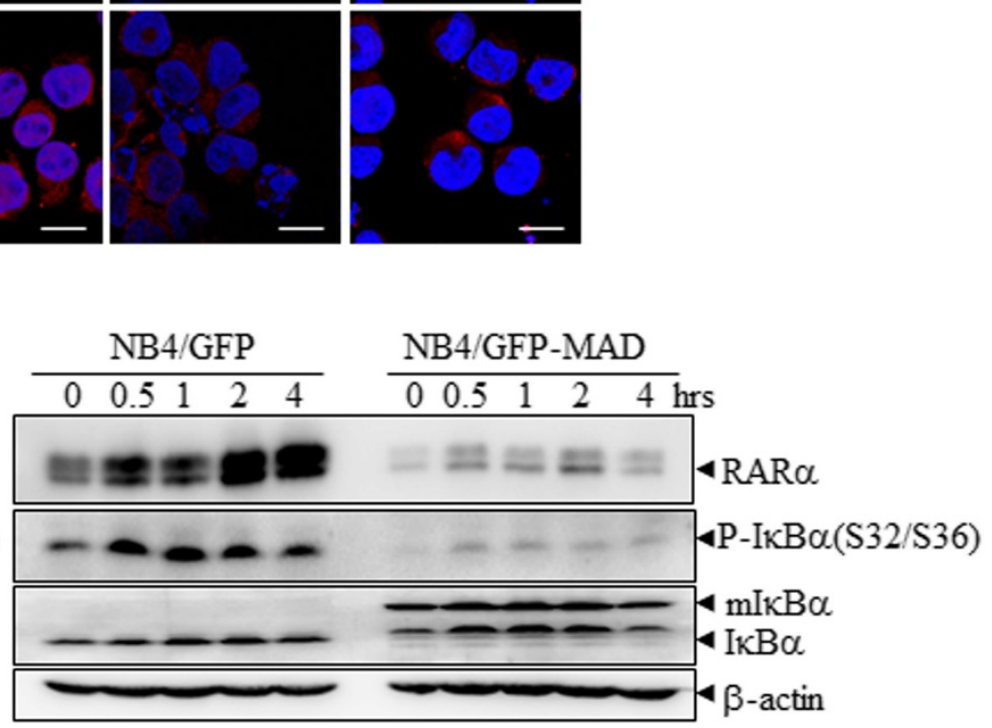

D NC sh-p 65

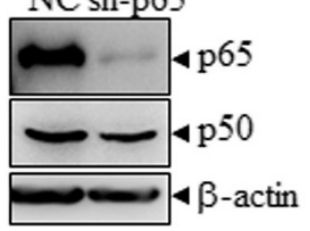

$\mathbf{E}$
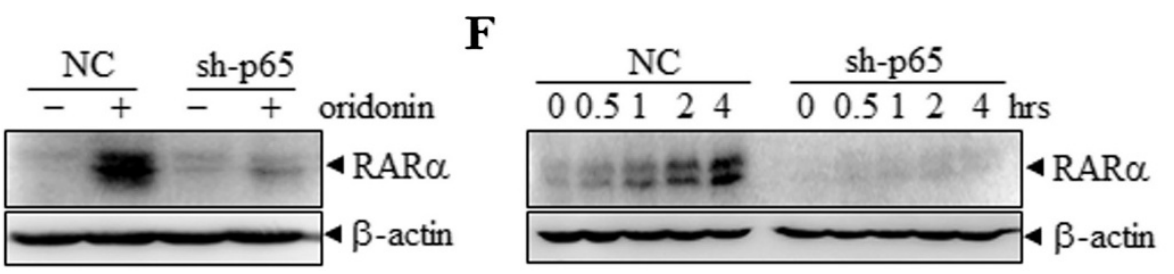

Figure 5 Oridonin-induced RAR $a$ stability requires the activation and nuclear translocation of p65. (A) NB4/GFP and NB4/GFP-MAD cells were treated with $10 \mu \mathrm{M}$ oridonin for $12 \mathrm{~h}$. The intracellular localization of p65 was analyzed using anti-p65 antibodies (red) with DAPI staining (blue) for nuclei. Scale bars represent $20 \mu \mathrm{m}$. (B, C) NB4/GFP and NB4/GFP-MAD cells were treated with $10 \mu \mathrm{M}$ oridonin for $12 \mathrm{~h}$ (B) or treated with $5 \mu \mathrm{M} \mathrm{H}_{2} \mathrm{O}_{2}$ for the times indicated (C), and the cell lysates were western blotted for the indicated proteins. (D) NB4 cells were infected with pSIREN-RetroQ-derived retroviruses carrying shRNA for p65 or scrambled shRNA as a control, and the cell lysates were western blotted for the indicated proteins. (E, F) NB4-NC and NB4-sh-p65 cells were treated with $10 \mu \mathrm{M}$ oridonin for $12 \mathrm{~h}$ (E) or with $5 \mu \mathrm{M} \mathrm{H} \mathrm{H}_{2} \mathrm{O}_{2}$ for the times indicated (F), and the cell lysates were western blotted for proteins as indicated. All experiments were repeated three times and gave consistent results. 
were inhibited in NB4/GFP-MAD cells compared with NB4/GFP cells (Figure 5B and C). Furthermore, we stably transfected NB4 cells with shRNA specifically against the p65 subunit of the NF- $k B$ family, which effectively silenced the expression of p65 but not p50 (Figure 5D). Notably, p65 knockdown prevented oridonin and $\mathrm{H}_{2} \mathrm{O}_{2}$ induced RAR $\alpha$ stability in NB4 cells (Figure 5E and F). Collectively, these results suggest that the activation and nuclear translocation of p65 is essential for oridonin to stabilize RAR $\alpha$.

\section{Promotion of p65 nuclear translocation increases RARa stability}

It is well known that TNF $\alpha$ is a classical activator of NF$\mathrm{KB}$ signaling; therefore, we investigated the consequence of TNF $\alpha$ treatment on RAR $\alpha$ expression to address whether oridonin-induced RAR $\alpha$ stability is mediated specifically by ROS-activated NF-kB activation. Our results showed that TNF $\alpha$ treatment also resulted in a strong increase in RAR $\alpha$ expression together with activation and nuclear translocation of NF-kB-p65 in NB4 cells (Figure 6A and B). This TNF $\alpha$-induced RAR $\alpha$ stability could be inhibited by p65 knockdown (Figure 6C). In addition, the over-expression of $\operatorname{IkB} \alpha \quad(\mathrm{A} 32 / 36)$ blocked the nuclear translocation of p65 and RAR $\alpha$ stability induced by TNF $\alpha$ (Figure 6D and E). All these data support the idea that translocation of p65 nuclear induces RAR $\alpha$ stability.

\section{Discussion}

In this study, we report that the natural diterpenoid, oridonin, induces a moderate production of cellular ROS that activates upstream of the NF- $\mathrm{KB}$ signaling pathway to cause nuclear translocation of p65, which is responsible for oridonin-stabilized RAR $\alpha$ protein. These findings indicate that moderate oxidative stress induced by
$\mathbf{A}$
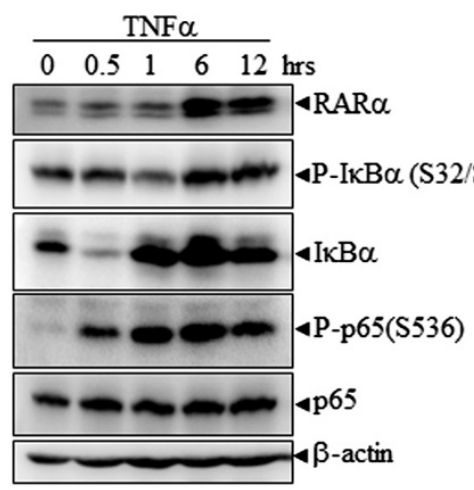

D

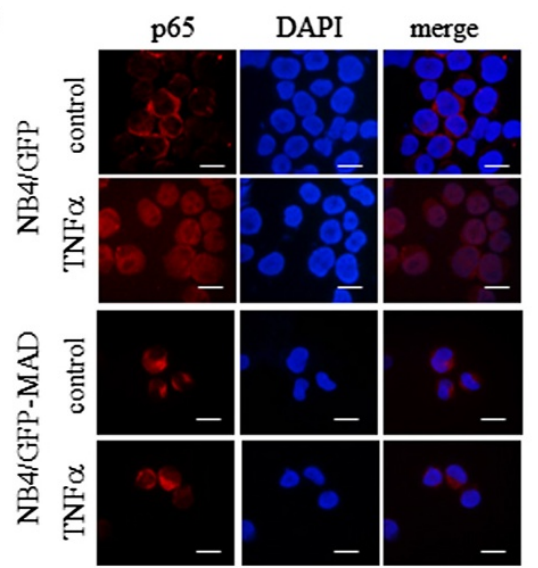

B

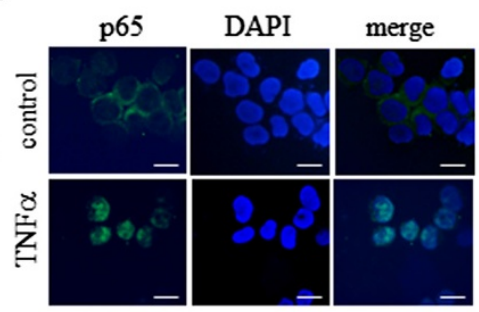

C

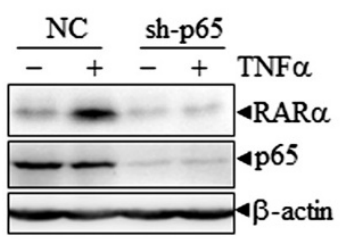

$\mathbf{E}$

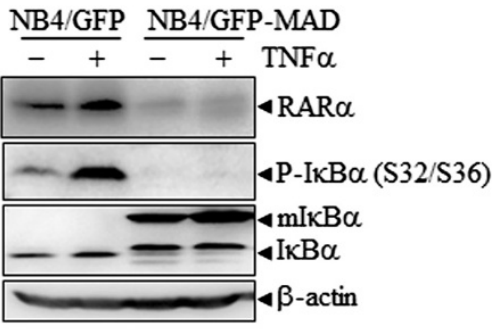

Figure 6 TNFa stabilizes RARa protein by activating NF-KB. (A) NB4 cells were treated with $10 \mathrm{ng} / \mathrm{mL}$ TNFa for the times indicated, followed by western blotting for proteins as indicated. (B) NB4 cells were treated with $10 \mathrm{ng} / \mathrm{mL}$ TNFa for $0.5 \mathrm{~h}$, followed by immunofluorescent staining using anti-p65 antibodies. (C) NB4 cells with NC or sh-p65 infection were treated with $10 \mathrm{ng} / \mathrm{mL}$ TNFa for $12 \mathrm{~h}$, followed by western blot analysis for proteins as indicated. (D) NB4/GFP and NB4/GFP-MAD cells were treated with $10 \mathrm{ng} / \mathrm{mL}$ TNFa for $0.5 \mathrm{~h}$, and then the intracellular localization of p65 was analyzed by immunofluorescence. (E) NB4/GFP and NB4/GFP-MAD cells were treated with $10 \mathrm{ng} / \mathrm{mL}$ TNFa for $12 \mathrm{~h}$. The cell lysates were western blotted for the indicated proteins. All experiments were repeated three times and gave consistent results. 
oridonin may change the intrinsic mechanisms that regulate RAR $\alpha$ protein stability through the NF-кB signaling pathway, which provides a new perspective of oridonin as a candidate anti-neoplastic drug.

The modulation of RAR $\alpha$ by ATRA during APL treatment has stimulated considerable interest in RAR $\alpha$ metabolism and its potential therapeutic mechanism [37]. ATRA activates RAR $\alpha$ signaling with subsequent effects on differentiation, while at the same time steady-state RAR $\alpha$ protein levels are markedly reduced [12]. RAR $\alpha$, as the receptor for ATRA, is required for its action; therefore, RAR $\alpha$ degradation is thought to be an inbuilt resetting mechanism to make ATRA signaling self-limiting. Therefore, it is possible that stabilizing the RAR $\alpha$ protein can optimize this signaling, which indicates that RAR $\alpha$ could be a potential target for cancer therapeutics. Recently, several studies have demonstrated that some compounds, such as lithium chloride ( $\mathrm{LiCl})$ [38], granulocyte-colony stimulating factor [38], STI571 [39], di-tert-butyl-benzohydroquinone [40], Pharicin B [15], and oridonin [23], which are capable of attenuating ATRA-induced loss of RAR $\alpha$ protein, have been shown to enhance ATRA-induced differentiation. However, the underlying mechanism of RAR $\alpha$ accumulation has not been fully described. In this work, we used oridonin as a probe to show that a moderate level of oxidative stress can stabilize RAR $\alpha$ protein through the nuclear translocation of p65. Further investigation is needed to test whether this mechanism can be extended to other small molecules with similar RAR $\alpha$-stabilizing ability. In addition, because RAR $\alpha$ is an essential transcriptional and homeostatic regulator of a plethora of physiological processes, numerous investigations have established correlations between down-regulation of RAR $\alpha$ and malignant progression. In addition to APL, this has been observed in cervical carcinoma [41], skin tumors [42], motor neuron disease [43], and breast cancer [44]. In this context, stabilizing RAR $\alpha$ may permit optimized use of retinoids in cancer prevention and treatment, which warrants further investigation.

It is now widely accepted that a moderate degree of ROS can play an important role in determining cell fate through the modulation of cellular signaling and gene expression $[45,46]$. For example, elevated but sub-lethal levels of ROS can modulate the differentiation of various types of cells, such as hematopoietic cells $[47,48]$, neurons [49], embryonic stem cells [50], osteoclasts [51], and cardiac stem cells [52]. However, little is known regarding the molecular targets of ROS. Here, we found that moderately increased levels of ROS are crucial for oridonin-induced RAR $\alpha$ stabilization, which may account for the anti-neoplastic mechanism of oridonin. It is tempting to suggest that this newly identified mechanism may underlie similar differentiation effects of some natural diterpenoids. Nevertheless, attention should be paid to the cell type, as well as to the extent and duration of ROS increase, as these factors can determine the precise consequences of the cellular response to oxidative stress. For instance, a relatively high concentration of $\mathrm{H}_{2} \mathrm{O}_{2}(0.1 \mathrm{mM})$ can suppress retinoid signaling through the proteasomal degradation of RAR $\alpha$ [14].

The NF- $\mathrm{kB}$ family is a group of transcriptional factors consisting of p65 (RelA), RelB, c-Rel, p50/p105, and $\mathrm{p} 52 / \mathrm{p} 100$. In the classical NF- $\mathrm{kB}$ signaling pathway, the $\mathrm{p} 50 / \mathrm{p} 65$ dimer is sequestered in the cytoplasm by IкB $\alpha$. After stimulation, IкB $\alpha$ is phosphorylated and consequently degraded through the proteasomal pathway. Thus, the p50/p65 dimer is released, translocates to the nucleus, and activates target genes [53]. In this report, we revealed that oridonin stabilizes RAR $\alpha$ protein by inducing nuclear translocation of $\mathrm{p} 65$, which was evidenced by the use of the ROS scavenger, NAC, the NF-kB inhibitor, Bay 117082, IкB $\alpha(\mathrm{A} 32 / 36)$ over-expression, and p65 knockdown. Moreover, we tested whether TNF $\alpha$, a classical activator of NF- $\mathrm{kB}$ signaling, modulates stability of RAR $\alpha$ protein. As expected, TNF $\alpha$ treatment also strongly increased RAR $\alpha$ expression, which may account, at least in part, for TNF $\alpha$-induced differentiation in some leukemia cells [54,55]. Previous studies indicated that oridonin mainly activates the upstream of the NF- $\mathrm{KB}$ signaling pathway, while its inhibitory effect is due to the direct interference of NF-kB DNA binding activity [56-59]. Leung et al. demonstrated that oridonin decreased the DNA binding activity of NF- $k B$ without interfering with p65 translocation [59]. Of note, the exact mechanisms by which activated NF-kB stabilizes RAR $\alpha$ protein require further investigation.

\section{Conclusions}

Our results indicate that oridonin stabilizes RAR $\alpha$ protein by increasing the levels of cellular ROS, followed by activation of the NF- $\kappa \mathrm{B}$ signaling pathway. Accordingly, the NF- $\kappa B$ activator, TNF $\alpha$, can also increase the stability of RAR $\alpha$ protein. These findings suggest a new mechanism underlying the regulation of RAR $\alpha$ protein stability and shed new light on understanding potential therapeutic roles of oridonin in leukemia and other RAR $\alpha$ related diseases.

\footnotetext{
Abbreviations

AML: Acute myeloid leukemia; APL: Acute promyelocytic leukemia; ATRA: All-trans retinoic acid; $\mathrm{CHX}$ : cycloheximide; $\mathrm{H}_{2} \mathrm{O}_{2}$ : Hydrogen peroxide; IKB: Inhibitor of NF-kB; IKK: IKB kinase; LiCl: Lithium chloride; NAC: N-acetyl-I-cysteine; NF-kB: Nuclear factor-kappa B; PML: Promyelocytic leukemia; RARa: Retinoic acid receptor alpha; ROS: Reactive oxygen species; RXRs: Retinoid X receptors; shRNAs: Short hairpin interfering RNAs.
}

Competing interests

The authors declare that they have no competing interest. 


\section{Authors' contributions}

Conceived and designed the experiments: HY, YLW. Performed all the experiments and analyzed the data: YC, WW. Contributed reagents/materials/ analysis tools: NZ, QY, WBX, WJY. Wrote the manuscript: YC, WW, GQC, YLW. Revised the manuscript: GQC, HY, YLW. All authors read and approved the final manuscript.

\section{Acknowledgements}

This work was supported in part by grants from the National Basic Research Program of China (973 Program) (NO. 2010CB912104, 2015CB910403), National Natural Science Foundation of China (81170509, 81272886 91313303), and Science and Technology Committee of Shanghai (11JC1406500)

\section{Author details}

${ }^{1}$ Department of Hematology, Rui-Jin Hospital, Shanghai Jiao-Tong University School of Medicine, Shanghai, China. ${ }^{2}$ Department of Hematology, Xinhua Hospital, Shanghai Jiao-Tong University School of Medicine, Shanghai, China. ${ }^{3}$ Department of Pathophysiology, Chemical Biology Division of Shanghai Universities E-Institutes, Key Laboratory of Cell Differentiation and Apoptosis of National Ministry of Education, Shanghai Jiao-Tong University School of Medicine, Shanghai, China.

\section{Received: 15 July 2014 Accepted: 19 March 2015}

\section{Published online: 10 April 2015}

\section{References}

1. Garattini E, Bolis M, Garattini SK, Fratelli M, Centritto F, Paroni G, et al. Retinoids and breast cancer: From basic studies to the clinic and back again. Cancer Treat Rev. 2014;40:739-49.

2. Collins SJ. Retinoic acid receptors, hematopoiesis and leukemogenesis. Curr Opin Hematol. 2008;15:346-51.

3. Lee YS, Jeong WI. Retinoic acids and hepatic stellate cells in liver disease. J Gastroenterol Hepatol. 2012;27 Suppl 2:75-9.

4. Orfali N, McKenna SL, Cahill MR, Gudas LJ, Mongan NP. Retinoid receptor signaling and autophagy in acute promyelocytic leukemia. Exp Cell Res. 2014;324:1-12.

5. Tang XH, Gudas LJ. Retinoids, retinoic acid receptors, and cancer. Annu Rev Pathol. 2011;6:345-64.

6. Zhang XW, Yan XJ, Zhou ZR, Yang FF, Wu ZY, Sun HB, et al. Arsenic trioxide controls the fate of the PML-RARalpha oncoprotein by directly binding PML. Science. 2010;328:240-3.

7. Wang $Z Y$, Chen Z. Acute promyelocytic leukemia: from highly fatal to highly curable. Blood. 2008;111:2505-15.

8. Dos Santos GA, Kats L, Pandolfi PP. Synergy against PML-RARa: targeting transcription, proteolysis, differentiation, and self-renewal in acute promyelocytic leukemia. J Exp Med. 2013;210:2793-802

9. Zheng XM, Seshire A, Ruester B, Bug G, Beissert T, Puccetti E, et al. Arsenic but not all-trans retinoic acid overcomes the aberrant stem cell capacity of PML/RAR alpha-positive leukemic stem cells. Haematologica. 2007;92:323-31.

10. Chen GQ, Shi XG, Tang W, Xiong SM, Zhu J, Cai $X$, et al. Use of arsenic trioxide (As2O3) in the treatment of acute promyelocytic leukemia (APL): I. As2O3 exerts dose-dependent dual effects on APL cells. Blood. 1997;89:3345-53.

11. Bleul T, Ruhl R, Bulashevska S, Karakhanova S, Werner J, Bazhin AV. Reduced retinoids and retinoid receptors' expression in pancreatic cancer: A link to patient survival. Mol Carcinog 2014 Apr 11. doi: 10.1002/mc.22158

12. Zhu J, Gianni M, Kopf E, Honore N, Chelbi-Alix M, Koken M, et al. Retinoic acid induces proteasome-dependent degradation of retinoic acid receptor alpha (RARalpha) and oncogenic RARalpha fusion proteins. Proc Natl Acad Sci U S A. 1999;96:14807-12.

13. Srinivas H, Juroske DM, Kalyankrishna S, Cody DD, Price RE, Xu XC, et al. c-Jun N-terminal kinase contributes to aberrant retinoid signaling in lung cancer cells by phosphorylating and inducing proteasomal degradation of retinoic acid receptor alpha. Mol Cell Biol. 2005;25:1054-69.

14. Hoshikawa Y, Kanki K, Ashla AA, Arakaki Y, Azumi J, Yasui T, et al. c-Jun $\mathrm{N}$-terminal kinase activation by oxidative stress suppresses retinoid signaling through proteasomal degradation of retinoic acid receptor alpha protein in hepatic cells. Cancer Sci. 2011;102:934-41.
15. Gu ZM, Wu YL, Zhou MY, Liu CX, Xu HZ, Yan H, et al. Pharicin B stabilizes retinoic acid receptor-alpha and presents synergistic differentiation induction with ATRA in myeloid leukemic cells. Blood. 2010;116:5289-97.

16. Chen G, Wang K, Yang BY, Tang B, Chen JX, Hua ZC. Synergistic antitumor activity of oridonin and arsenic trioxide on hepatocellular carcinoma cells. Int J Oncol. 2012;40:139-47.

17. Li X, Li X, Wang J, Ye Z, Li JC. Oridonin up-regulates expression of P21 and induces autophagy and apoptosis in human prostate cancer cells. Int J Biol Sci. 2012:8:901-12.

18. Wang S, Zhong Z, Wan J, Tan W, Wu G, Chen M, et al. Oridonin induces apoptosis, inhibits migration and invasion on highly-metastatic human breast cancer cells. Am J Chin Med. 2013;41:177-96.

19. Zhou GB, Kang H, Wang L, Gao L, Liu P, Xie J, et al. Oridonin, a diterpenoid extracted from medicinal herbs, targets AML1-ETO fusion protein and shows potent antitumor activity with low adverse effects on t(8;21) leukemia in vitro and in vivo. Blood. 2007;109:3441-50.

20. Li CY, Wang EQ, Cheng Y, Bao JK. Oridonin: An active diterpenoid targeting cell cycle arrest, apoptotic and autophagic pathways for cancer therapeutics. Int J Biochem Cell Biol. 2011:43:701-4.

21. Hu AP, Du JM, Li JY, Liu JW. Oridonin promotes CD4+/CD25+ Treg differentiation, modulates Th1/Th2 balance and induces $\mathrm{HO}-1$ in rat splenic lymphocytes. Inflamm Res. 2008;57:163-70

22. Ren KK, Wang HZ, Xie LP, Chen DW, Liu X, Sun J, et al. The effects of oridonin on cell growth, cell cycle, cell migration and differentiation in melanoma cells. J Ethnopharmacol. 2006;103:176-80.

23. Gao F, Tang Q, Yang P, Fang Y, Li W, Wu Y. Apoptosis inducing and differentiation enhancement effect of oridonin on the all-trans-retinoic acid-sensitive and -resistant acute promyelocytic leukemia cells. Int J Lab Hematol. 2010;32:e114-22.

24. Komura E, Tonetti C, Penard-Lacronique V, Chagraoui H, Lacout C, Lecouedic JP, et al. Role for the nuclear factor kappaB pathway in transforming growth factor-beta1 production in idiopathic myelofibrosis: possible relationship with FK506 binding protein 51 overexpression. Cancer Res. 2005;65:3281-9.

25. De The H, Vivanco-Ruiz MM, Tiollais P, Stunnenberg H, Dejean A. Identification of a retinoic acid responsive element in the retinoic acid receptor beta gene. Nature. 1990;343:177-80.

26. Duprez E, Wagner $\mathrm{K}$, Koch H, Tenen DG. C/EBPbeta: a major PML-RARAresponsive gene in retinoic acid-induced differentiation of APL cells. EMBO J. 2003;22:5806-16.

27. Mao M, Yu M, Tong JH, Ye J, Zhu J, Huang QH, et al. RIG-E, a human homolog of the murine Ly- 6 family, is induced by retinoic acid during the differentiation of acute promyelocytic leukemia cell. Proc Natl Acad Sci U S A. 1996;93:5910-4.

28. Matikainen S, Ronni T, Hurme M, Pine R, Julkunen I. Retinoic acid activates interferon regulatory factor-1 gene expression in myeloid cells. Blood. 1996:88:114-23.

29. Wang H, Ye Y, Yu ZL. Proteomic and functional analyses demonstrate the involvement of oxidative stress in the anticancer activities of oridonin in HepG2 cells. Oncol Rep. 2014;31:2165-72.

30. Zang L, He H, Xu Q, Yu Y, Zheng N, Liu W, et al. Reactive oxygen species $\mathrm{H} 2 \mathrm{O} 2$ and ${ }^{*} \mathrm{OH}$, but not $\mathrm{O}^{*}(-)$ promote oridonin-induced phagocytosis of apoptotic cells by human histocytic lymphoma U937 cells. Int Immunopharmacol. 2013;15:414-23.

31. Nicholls P. Classical catalase: ancient and modern. Arch Biochem Biophys. 2012;525:95-101.

32. Zuo $Y$, Xiang B, Yang J, Sun $X$, Wang $Y$, Cang $H$, et al. Oxidative modification of caspase- 9 facilitates its activation via disulfide-mediated interaction with Apaf-1. Cell Res. 2009;19:449-57.

33. Rhee SG, Kang SW, Jeong W, Chang TS, Yang KS, Woo HA. Intracellular messenger function of hydrogen peroxide and its regulation by peroxiredoxins. Curr Opin Cell Biol. 2005;17:183-9.

34. Sies H. Role of Metabolic H2O2 Generation: REDOX SIGNALING AND OXIDATIVE STRESS. J Biol Chem. 2014;289:8735-41.

35. Liu CX, Yin QQ, Zhou HC, Wu YL, Pu JX, Xia L, et al. Adenanthin targets peroxiredoxin I and II to induce differentiation of leukemic cells. Nat Chem Biol. 2012;8:486-93.

36. Traenckner EB, Pahl HL, Henkel T, Schmidt KN, Wilk S, Baeuerle PA Phosphorylation of human I kappa B-alpha on serines 32 and 36 controls I kappa B-alpha proteolysis and NF-kappa B activation in response to diverse stimuli. EMBO J. 1995;14:2876-83. 
37. Maire A, Alvarez S, Shankaranarayanan P, Lera AR, Bourguet W, Gronemeyer $H$. Retinoid receptors and therapeutic applications of RAR/RXR modulators. Curr Top Med Chem. 2012;12:505-27.

38. Finch RA, Li J, Chou TC, Sartorelli AC. Maintenance of retinoic acid receptor alpha pools by granulocyte colony-stimulating factor and lithium chloride in all-trans retinoic acid-treated WEHI-3B leukemia cells: relevance to the synergistic induction of terminal differentiation. Blood. 2000;96:2262-8.

39. Gianni M, Kalac Y, Ponzanelli I, Rambaldi A, Terao M, Garattini E. Tyrosine kinase inhibitor STI571 potentiates the pharmacologic activity of retinoic acid in acute promyelocytic leukemia cells: effects on the degradation of RARalpha and PML-RARalpha. Blood. 2001;97:3234-43.

40. Launay S, Gianni M, Diomede L, Machesky LM, Enouf J, Papp B. Enhancement of ATRA-induced cell differentiation by inhibition of calcium accumulation into the endoplasmic reticulum: cross-talk between RAR alpha and calcium-dependent signaling. Blood. 2003;101:3220-8.

41. Geisen C, Denk C, Gremm B, Baust C, Karger A, Bollag W, et al. High-level expression of the retinoic acid receptor beta gene in normal cells of the uterine cervix is regulated by the retinoic acid receptor alpha and is abnormally down-regulated in cervical carcinoma cells. Cancer Res. 1997:57:1460-7.

42. Darwiche N, Scita G, Jones C, Rutberg S, Greenwald E, Tennenbaum T, et al. Loss of retinoic acid receptors in mouse skin and skin tumors is associated with activation of the $\operatorname{ras}(\mathrm{Ha})$ oncogene and high risk for premalignant progression. Cancer Res. 1996;56:4942-9.

43. Corcoran J, So PL, Maden M. Absence of retinoids can induce motoneuron disease in the adult rat and a retinoid defect is present in motoneuron disease patients. J Cell Sci. 2002;115:4735-41.

44. Han QX, Allegretto EA, Shao ZM, Kute TE, Ordonez J, Aisner SC, et al. Elevated expression of retinoic acid receptor-alpha (RAR alpha) in estrogen-receptor-positive breast carcinomas as detected by immunohistochemistry. Diagn Mol Pathol. 1997;6:42-8.

45. Bae YS, Oh H, Rhee SG, Yoo YD. Regulation of reactive oxygen species generation in cell signaling. Mol Cells. 2011;32:491-509.

46. Ray PD, Huang BW, Tsuji Y. Reactive oxygen species (ROS) homeostasis and redox regulation in cellular signaling. Cell Signal. 2012;24:981-90.

47. Jang YY, Sharkis SJ. A low level of reactive oxygen species selects for primitive hematopoietic stem cells that may reside in the low-oxygenic niche. Blood. 2007;110:3056-63.

48. Abdel-Wahab O, Levine RL. Metabolism and the leukemic stem cell. J Exp Med. 2010;207:677-80

49. Tsatmali M, Walcott EC, Makarenkova H, Crossin KL. Reactive oxygen species modulate the differentiation of neurons in clonal cortical cultures. Mol Cell Neurosci. 2006;33:345-57.

50. Ji AR, Ku SY, Cho MS, Kim YY, Kim YJ, Oh SK, et al. Reactive oxygen species enhance differentiation of human embryonic stem cells into mesendodermal lineage. Exp Mol Med. 2010;42:175-86.

51. Lee NK, Choi YG, Baik JY, Han SY, Jeong DW, Bae YS, et al. A crucial role for reactive oxygen species in RANKL-induced osteoclast differentiation. Blood. 2005;106:852-9.

52. Sauer $H$, Wartenberg M. Reactive oxygen species as signaling molecules in cardiovascular differentiation of embryonic stem cells and tumor-induced angiogenesis. Antioxid Redox Signal. 2005;7:1423-34.

53. Hayden MS, Ghosh S. Signaling to NF-kappaB. Genes Dev. 2004;18:2195-224.

54. Secchiero P, Milani D, Gonelli A, Melloni E, Campioni D, Gibellini D, et al. Tumor necrosis factor (TNF)-related apoptosis-inducing ligand (TRAIL) and TNF-alpha promote the NF-kappaB-dependent maturation of normal and leukemic myeloid cells. J Leukoc Biol. 2003;74:223-32.

55. Mudipalli A, Li Z, Hromchak R, Bloch A. NF-kappaB (p65/RelA) as a regulator of TNFalpha-mediated ML-1 cell differentiation. Leukemia. 2001;15:808-13.

56. Zhang Y, Wu Y, Wu D, Tashiro S, Onodera S, Ikejima T. NF-kappab facilitates oridonin-induced apoptosis and autophagy in HT1080 cells through a p53-mediated pathway. Arch Biochem Biophys. 2009;489:25-33.

57. Zang L, He H, Ye Y, Liu W, Fan S, Tashiro S, et al. Nitric oxide augments oridonin-induced efferocytosis by human histocytic lymphoma U937 cells via autophagy and the NF-kappaB-COX-2-IL-1 beta pathway. Free Radic Res. 2012;46:1207-19.
58. Ikezoe T, Yang Y, Bandobashi K, Saito T, Takemoto S, Machida H, et al. Oridonin, a diterpenoid purified from Rabdosia rubescens, inhibits the proliferation of cells from lymphoid malignancies in association with blockade of the NF-kappa B signal pathways. Mol Cancer Ther. 2005:4:578-86.

59. Leung CH, Grill SP, Lam W, Han QB, Sun HD, Cheng YC. Novel mechanism of inhibition of nuclear factor-kappa B DNA-binding activity by diterpenoids isolated from Isodon rubescens. Mol Pharmacol. 2005;68:286-97.

\section{Submit your next manuscript to BioMed Central and take full advantage of:}

- Convenient online submission

- Thorough peer review

- No space constraints or color figure charges

- Immediate publication on acceptance

- Inclusion in PubMed, CAS, Scopus and Google Scholar

- Research which is freely available for redistribution 